\title{
Kajian Peningkatan Kualitas Briket Arang Campuran Sekam Padi Dengan Buah Pinus Sebagai Sumber Energi Alternatif
}

\author{
Sallolo Suluh( ${ }^{(1)}$, Ir. Petrus Sampelawang ${ }^{(2)}, \operatorname{Mesak}^{(3)}$ \\ Prodi Teknik Mesin Fakultas Teknik \\ Universitas Kristen Indonesia Toraja \\ Tana Toraja \\ Sulawesi Selatan, Indonesia
}

\begin{abstract}
Abstrak
Penelitian ini bertujuan (1) Untuk mengetahui nilai kalor dari briket arang buah pinus dengan sekam padi berdasarkan komposisi bahan. (2) Untuk mengetahui efisiensi thermal pembakaran briket arang campuran buah pinus dengan sekam padi berdasarkan komposisi bahan.

Metode penelitian yang digunakan metode experimental dengan memanfaatkan campuran buah pinus dengan sekam padi komposisi campuran bahan yang telah dicetak dan menghasilkan bentuk briket sarang tawon sebagai bahan bakar pada kompor untuk mendidihkan air.

Penelitian ini dilakukan di Laboratorium nutrisi dan makanan ternak Fakultas Peternakan Universitas Hasanuddin dan Laboratorium teknik mesin UKI Toraja.
\end{abstract}

Hasil uji nilai kalor rata - rata yaitu briket KK1 diperoleh $6023 \mathrm{Cal} / \mathrm{gr}$, KK2 diperoleh $5861.33 \mathrm{Cal} / \mathrm{gr}, \mathrm{KK} 35652.66 \mathrm{Cal} / \mathrm{gr}$. Hasil uji pembakaran pada 3 jenis briket yang berbeda menunjukkan bahwa briket KK1 yang paling unggul dalam hal kemampuan untuk mendidihkan air yaitu sebanyak lima kali dan efisiensi pembakarannya sebesar $62.7 \%$, kemudian briket KK2 mendidihkan air sebanyak dua kali dengan efisiensi sebesar $25 \%$ dan paling rendah yaitu briket KK3 mendidihkan air sebanyak dua kali dengan efisiensi sebesar $22 \%$.

Kata kunci : Briket arang, buah pinus, sekam padi, nilai kalor, dan efisiensi thermal. 


\section{PENDAHULUAN}

Kebutuhan energi di Indonesia saat ini masih sangat bergantung pada bahan bakar minyak. Untuk rumah tangga sebagian besar kebutuhan energinya mengandalkan minyak bumi dan gas elpiji. Oleh karena itu, usaha untuk mencari bahan bakar alternatif yang dapat diperbarui (renewable), ramah lingkungan dan bernilai ekonomis, semakin banyak dilakukan. Salah satu energi terbarukan yang perlu mendapatkan perhatian untuk dikembangkan adalah biomassa. Biomassa secara umum dikenal sebagai bahan kering material organik atau bahan yang tersisa setelah suatu tanaman atau material organik dihilangkan kadar airnya. Biomassa sangat mudah ditemukan dari aktifitas pertanian, kehutanan, perkebunan, peternakan, perikanan dan limbah-limbah lainnya. Limbah biomassa menjadi salah satu pilihan sumber energi alternatif. Salah satu contoh pemanfaatan energi biomassa yang berasal dari produk limbah aktifitas pertanian dan kehutanan yang akan difokuskan dalam penelitian adalah sekam padi dan limbah buah pinus.

Toraja utara kaya akan sumber daya alamnya ini terlihat dari sebagian besar penduduk mengantungkan hidup dengan bertani. Sehingga limbah pertanian seperti sekam padi sangat melimpah. Limbah pertanian tersebut hanya digunakan sebagai bahan bakar tungku, dibuang atau dibakar begitu saja, sehingga dapat menimbulkan pencemaran lingkungan. Sekam padi merupakan biomassa yang belum termanfaatkan secara optimal. Adapun penelitian sebelumnya yang mendukung penelitian ini adalah mahatir pada tahun 2010 mengkombinasikan sekam padi dengan limbang ketam kayu merbabu dan tongkol jagung. Dimana hasil nilai kalor didapatkan paling rendah yaitu $3220 \mathrm{kal} / \mathrm{kg}$. sehingga penulis tertarik untuk mengkombinasikan dengan buah pinus. Dimana Limbah buah pinus yang merupakan aktivitas kehutanan dan perkebunan sangat melimpah di Sulawesi selatan khususnya toraja utara. Menurut data dari Dinas Kehutanan dan Perkebunan Toraja utara tahun 2015 bahwa 1 ha lahan ditanami 1800 pohon pinus dengan jarak tanam 2 × 3 meter. Dan produksi normal dari buah pinus dalam 1 pohon berkisar 70-80 kg atau rata-rata $75 \mathrm{~kg}$. Dalam 1 tahun pohon pinus berbuah 2 kali yaitu dari bulan April - Juli dan bulan November - Desember. Dari total 
luas lahan dikali dengan jumlah pohon / ha maka jumlah pohon pinus yang ada berkisar 577.500 pohon. Sehingga buah pinus yang dihasilkan dalam setahun yaitu : 577.500 pohon x $50 \mathrm{~kg}=28.875 .000 \mathrm{~kg}$ x $2 \mathrm{kali}$ pembuahan $=57.750 .000$ $\mathrm{kg}$ atau 57.750 ton/ tahun.

Melihat hasil sekam padi dan buah pinus yang tersedia di Kabupaten Toraja Utara melimpah, maka sangat potensial untuk di manfaatkan sebagai pengganti bahan bakar atau sebagai energi alternatif dalam bentuk briket arang.

Briket arang sekam padi dan buah pinus dikombinasikan dengan berbagai komposisi untuk mendapatkan sifat-sifat penyalaan dan kualitas pembakaran yang lebih baik lagi.

Berdasarkan uraian pada latar belakang di atas, maka penulis tertarik untuk mengambil judul: "KAJIAN PENINGKATAN KUALITAS BRIKET CAMPURAN SEKAM PADI DENGAN BUAH

\section{Briket Bioarang}

Briket bioarang adalah gumpalan-gumpalan atau batangan-batangan arang yang terbuat dari bioarang (bahan lunak). Bioarang yang sebenarnya termasuk bahan lunak dengan proses tertentu diolah menjadi bahan arang keras dengan bentuk tertentu. Kualitas dari bioarang ini tidak kalah dengan batubara atau bahan bakar jenis arang lainnya (Joseph dan Hislop, 1981).

\section{Bahan Pengikat Lempung/Tanah Liat}

Lempung atau tanah liat merupakan tanah dengan butiran yang sangat halus, bersifat plastis (mudah dibentuk) dan mempunyai daya lekat. Lempung mempunyai sifat yang sangat spesifik, antara lain mempunyai sifat muai susut yang sangat besar dalam keadaan aslinya, tetapi setelah lempung diolah, maka sifat muai susut yang besar ini dapat dihilangkan, sehingga dapat digunakan sebagai bahan bangunan olahan.

\section{Bahan Perekat Tepung Tapioka}

Tepung singkong (tepung tapioka) atau aci adalah tepung yang diperoleh dari umbi akar singkong. Tapioka memiliki sifat-sifat fisik yang serupa dengan tepung 
sagu, sehingga penggunaan keduanya dapat dipertukarkan. Tepung ini sering digunakan untuk membuat makanan dan bahan perekat.

\section{Nilai Kalor}

Nilai kalor dapat dihitung dengan persamaan sebagai berikut:

$H H V\left(\frac{c u l}{g}\right)=\frac{[(\Delta i) E E V]-\left(e_{1}+t_{2}\right)}{m}-e_{a}\left(\frac{c u l}{g}\right) \ldots(2.1)$

Rumus yang digunakan berdasarkan standar ASTM D 5142 - 02)

Dimana :

$\Delta t \quad$ : Kenaikan suhu pembakaran pada bomb kalorimeter $\left({ }^{\circ} \mathrm{C}\right)$

EEV : energi ekuivalen saat terjadi pembakaran $\left({ }^{\circ} \mathrm{C}\right)$

$e_{1} \quad$ : koreksi panas kerena pembentukan asam (cal)

$e_{2} \quad$ : koreksi panas pembakaran dari kawat pembakaran (cal)

$e_{3} \quad$ : koreksi sulfur yang ada dalam bahan bakar (cal/g)

m : massa briket (g)

\section{Efisiensi Thermal Pembakaran Briket}

Efisiensi termal dapat dihitung sebagai berikut dengan rumus berikut :

$n^{t m}=\frac{\left(M a \times C_{p a r} \times\left(T_{a}-T_{b}\right)+\left(M_{p} \times C_{w a l} \times\left(T_{z}+T_{b}\right)\right)+(M u \times H l)\right.}{L H V \times M b b} \times 100$

Dimana :

$\eta_{\text {th }}$ : efisiensi termal pembakaran briket pada kompor briket(\%).

$\mathrm{M}_{\mathrm{a}} \quad$ : massa air mula-mula $(\mathrm{kg})$.

$\mathrm{M}_{\mathrm{bb}} \quad$ : massa briket yang telah terpakai dalam pendidihan $\operatorname{air}(\mathrm{kg})$.

$\mathrm{M}_{\mathrm{u}} \quad$ : massa uap air $(\mathrm{kg})$.

$\mathrm{H}_{L} \quad$ : Kalor laten dari uap $(\mathrm{kJ} / \mathrm{kg})$.

$\mathrm{Cp}_{\text {air }} \quad$ : kalor spesifik air $4,176\left(\mathrm{~kJ} / \mathrm{kg}{ }^{0} \mathrm{C}\right)$.

$\mathrm{Cp}_{\mathrm{al}} \quad$ : kalor spesifik Aluminium/bahan panci $\left(\mathrm{kJ} / \mathrm{kg}{ }^{0} \mathrm{C}\right)$.

$H H V$ : nilai kalor briket $(\mathrm{kJ} / \mathrm{kg})$.

$\mathrm{T}_{\mathrm{b}} \quad$ : temperatur ambien dari air $\left(27^{\circ} \mathrm{C}\right)$.

$\mathrm{T}_{\mathrm{a}} \quad$ : temperatur uap air $\left(100{ }^{\circ} \mathrm{C}\right)$

$\mathrm{T}_{\mathrm{c}} \quad$ : temperatur panci $\left({ }^{0} \mathrm{C}\right)$ 


\section{METODOLOGI PENELITIAN}

Metode penelitian yang digunakan adalah metode eksperimental dengan memanfaatkan buah pinus dengan sekam padi sebagai sumber energi alternatif dalam bentuk briket. Bentuk briket arang yang digunakan adalah bentuk sarang tawon karena berdasarkan beberapa penelitian sebelumnya bahwa bentuk sarang tawon mempunyai bidang permukaan nyala yang lebih besar sedangkan ukuran partikel arang sebesar 40 mesh. Selanjutnya dilakukan pengujian briket yaitu nilai kalor dan efisiensi thermal pembakaran briket buah pinus dan sekam padi pada kompor briket.

Tabel 3.1. Data komposisi campuran bahan.

\begin{tabular}{|c|c|c|c|c|}
\hline \multirow{2}{*}{$\begin{array}{c}\text { Kode } \\
\text { Sampel }\end{array}$} & \multicolumn{4}{|c|}{ Komposisi Bahan } \\
\cline { 2 - 5 } & $\begin{array}{c}\text { Buah Pinus } \\
\text { (gr) }\end{array}$ & $\begin{array}{c}\text { Sekam } \\
\text { Padi (gr) }\end{array}$ & Tanah Liat (gr) & $\begin{array}{c}\text { Tepung Tapioka } \\
\text { (gr) }\end{array}$ \\
\hline KK1 & 600 & 225 & 75 & 75 \\
\hline KK2 & 225 & 625 & 75 & 75 \\
\hline KK3 & 425 & 425 & 75 & 75 \\
\hline
\end{tabular}

\section{Bahan yang digunakan}

a. Buah pinus dan sekam padi, sebagai bahan untuk pembuatan briket.

b. Bubuk tepung kanji, sebagai bahan perekat.

c. Tanah liat, sebagai bahan penguat.

d. Air, sebagai bahan pelarut serbuk arang dan bahan perekat.

\section{Alat yang digunakan}

a. Mesin cetak briket sebagai alat pencetak briket buah pinus dan sekam padi.

b. Lesung sebagai tempat menghancurkan arang kulit kakao dan limbah kulit kopi.

c. Drum karbonisasi sebagai tempat pembakaran biah pinus dan sekam padi sampai menjadi arang. 
d. Ayakan (40-60 mesh) sebagai alat untuk memisahkan arang yang halus dengan kasar setelah dihancurkan.

e. Kompor briket sebagai alat pengujian mutu pembakaran briket buah pinus dan sekam padi yaitu kompor briket britubara.

f. Thermokopel yang digunakan untuk mengukur temperatur titik api dan titik air pada pengujian pembakaran.

g. Timbangan sebagai alat pengukur berat bahan briket

h. Ketel air sebagai pemanas air.

i. Bomb kalorimeter sebagai alat untuk mengukur besarnya nilai kalor

j. Panci aluminium sebagai tempat untuk memasak air.

\section{HASIL DAN PEMBAHASAN}

\section{Hasil Penelitian}

Hasil penelitian meliputi hasil pembuatan briket arang campuran buah pinus dan sekam padi, hasil pengujian nilai kalor, hasil pengujian pembakaran briket dan pendidihan air pada kompor briket, hasil pengujian efisiensi thermal.

\section{A. Pengujian nilai kalor}

Pengujian nilai kalor dilakukan di laboratorium kimia makanan ternak Fakultas Peternakan Unhas dengan hasil dapat dilihat pada Tabel 4.1.

Tabel 4.1. Hasil pengujian nilai kalor

\begin{tabular}{|c|cc|c|}
\hline No. & Kode Sampel & Nilai kalor (Cal/gr) \\
\hline 1 & KK1 $600: 250$ & 1 & 6023 \\
\hline 2 & KK1 $600: 250$ & 2 & 6034 \\
\hline 3 & KK1 $600: 250$ & 3 & 6012 \\
\hline \multicolumn{3}{|c|}{ Rata - rata KK1 } & 6023 \\
\hline 1 & KK2 $425: 425$ & 1 & 5874 \\
\hline 2 & KK2 $425: 425$ & 2 & 5844 \\
\hline 3 & KK2 $425: 425$ & 3 & 5866 \\
\hline
\end{tabular}




\begin{tabular}{|c|cc|c|}
\hline \multicolumn{3}{|c|}{ Rata - rata KK2 } & 5861.33 \\
\hline 1 & KK3 250:600 & 1 & 5698 \\
\hline 2 & KK3 250:600 & 2 & 5638 \\
\hline 3 & KK3 250:600 & 3 & 5622 \\
\hline \multicolumn{3}{|c|}{ Rata - rata KK3 } & 5652.66 \\
\hline
\end{tabular}

\section{B. Efisiensi thermal}

Efisiensi merupakan besarnya energi panas yang digunakan selama proses perubahan bentuk energi yang bermanfaat dibagi besarnya energi panas yang dilepaskan oleh bahan bakar selama proses pembakaran.

1. Perhitungan efisiensi thermal briket KK1

Briket KK1 dalam mendidihkan air sebanyak 5 kali dan temperatur api di dapatkan sebesar $617^{\circ} \mathrm{C}$ dengan waktu pembakaran briket selama 160 menit. Dan menghabiskan briket yang terbakar sebanyak $0.35 \mathrm{~kg}$. Selanjutnya dapat dilihat data-datanya sebagai berikut :

$$
\begin{array}{ll}
\mathrm{m}_{\mathrm{a}} & =\text { massa air yang dipanaskan }(\mathrm{kg})=0.8 \mathrm{~kg} \\
\mathrm{~m}_{\mathrm{p}} & =\text { massa panci }(\mathrm{kg})=0.25 \mathrm{~kg} \\
\mathrm{~m}_{\mathrm{bk}} & =\text { massa briket yang telah terpakai }(\mathrm{kg})=0.35 \mathrm{~kg} \\
\mathrm{~m}_{\mathrm{u}} & =\text { massa uap air }(\mathrm{kg})=0.65 \mathrm{~kg} \\
\mathrm{H}_{L} & =\text { Kalor laten dari uap }(\mathrm{kJ} / \mathrm{kg})=2256.487 \mathrm{~kJ} / \mathrm{kg} \\
\mathrm{C}_{\text {air }} & =\text { kalor spesifik air }\left(\mathrm{kJ} / \mathrm{kg}{ }^{0} \mathrm{C}=4.1769 \mathrm{~kJ} / \mathrm{kg}{ }^{0} \mathrm{C}\right. \\
\mathrm{C}_{\mathrm{al}} & =\text { kalor spesifik aluminium }\left(\mathrm{kJ} / \mathrm{kg}{ }^{\circ} \mathrm{C}\right)=0.9 \mathrm{~kJ} / \mathrm{kg}{ }^{\circ} \mathrm{C} \\
L H V & =\text { nilai kalor bawah briket }(\mathrm{kJ} / \mathrm{kg}) \\
& =(25217.096 \mathrm{~kJ} / \mathrm{kg}-3240 \mathrm{~kJ} / \mathrm{kg})=21977.096 \mathrm{~kJ} / \mathrm{kg} \\
\mathrm{T}_{\mathrm{b}} & =\text { temperatur air awal }\left({ }^{\circ} \mathrm{C}\right)=27{ }^{\circ} \mathrm{C} \\
\mathrm{T}_{\mathrm{a}} & =\text { temperatur didih air dalam panci }\left({ }^{\circ} \mathrm{C}\right)=100{ }^{\circ} \mathrm{C} \\
\mathrm{T}_{\mathrm{c}} & =\text { temperatur api }\left({ }^{\circ} \mathrm{C}\right)=617{ }^{\circ} \mathrm{C}
\end{array}
$$

Efisiensi thermal briket KK1 :

$\eta$ th $=\frac{Q_{\text {air }}+Q_{\text {panci }}}{m_{b b} \times L A V} \times 100 \%$ 


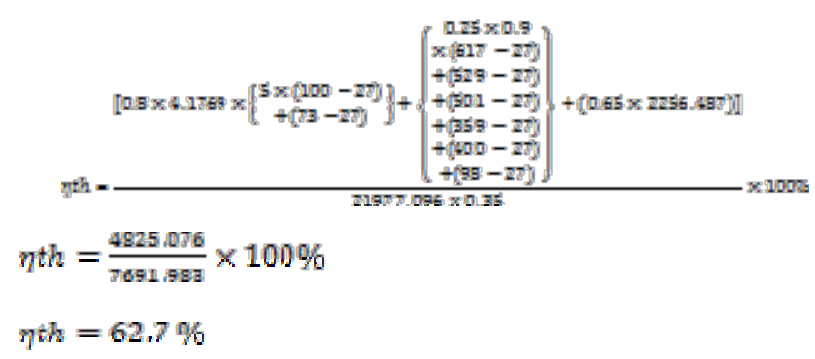

Hasil selanjutnyaperhitungan yang sama untuk KK2 dan KK3dapat dilihat pada tabel 4.2 dibawah ini

Tabel 4.2. Rekapitulasi pengujian efisiensi thermal

\begin{tabular}{|l|c|c|c|}
\hline \multirow{2}{*}{ Diketahui } & \multicolumn{3}{|c|}{ Kode Sampel } \\
\cline { 2 - 4 } & KK1 & KK2 & KK3 \\
\hline ma (kg) & 0.8 & 0.8 & 0.8 \\
\hline mu (kg) & 0.25 & 0.25 & 0.25 \\
\hline $\boldsymbol{H}_{\mathbf{L}(\mathbf{k j} / \mathbf{k g})}$ & 0.65 & 0.14 & 0.1 \\
\hline cp air (kJ/kg $\left.{ }^{\circ} \mathbf{C}\right)$ & 2256.487 & 2256.487 & 2256.487 \\
\hline cp al (kJ/kg) & 4.1769 & 4.1769 & 4.1769 \\
\hline Ta $\left({ }^{\circ} \mathbf{C}\right)$ & 0.9 & 0.9 & 0.9 \\
\hline Tb $\left({ }^{\circ} \mathbf{C}\right)$ & 100 & 100 & 100 \\
\hline Tc $\left({ }^{\circ} \mathbf{C}\right)$ & 27 & 27 & 27 \\
\hline Briket Terpakai (kg) & 0.35 & 0.35 & 0.35 \\
\hline LHV (kJ/kg) & 21977.09 & 21300.23 & 20426.58 \\
\hline $\boldsymbol{\eta}(\%)$ & 62.7 & 25 & 22 \\
\hline
\end{tabular}

\section{Pembahasan}

\section{Hasil pembuatan briket arang campuran buah pinus dan sekam padi}

Briket arang campuran buah pinus dan sekam padi telah berhasil dibuat dalam bentuk sarang tawon dengan mesin pencetak. Jumlah briket tempurung kelapa yang dihasilkan dalam penelitian ini sebanyak 30 buah. Sebelumya telah 
dilakukan berbagai usaha untuk meningkatkan kualitas briket itu sendiri antara lain : memaksimalkan penggeringan bahan baku sebelum dan sesudah penggarangan, kemudian memisahkan arang dan abu dengan menggunakan 1 jenis pasangan saringan 40 mesh, sehingga abu dapat terbuang. Selain itu juga ditambahkan tepung tapioka dan tanah liat dengan komposisi masing-masing 75 gr untuk menambah kerapatan dan kuat tekan briket.

\section{Hasil pengujian nilai kalor}

Tinggi rendahnya nilai kalor dipengaruhi oleh kadar air dan kadar abu briket arang. Semakin rendah nilai kadar air dan kadar abu briket arang maka akan meningkatkan nilai kalor briket arang. Hasil penelitian membuktikan jika kadar abu tinggi maka akan dihasilkan nilai kalor yang rendah atau sebaliknya. Selain itu nilai kalor juga dipengaruhi oleh nilai kadar karbon terikat yang terkandung didalam briket arang. Semakin tinggi nilai kadar karbon terikat dalam briket arang maka semakin tinggi pula nilai kalor briket arang.

Kandungan nilai kalor yang didapatkan untuk ketiga jenis briket campuran buah pinus dengan sekam padi dapat dilihat pada grafik 4.1, sebagai berikut:

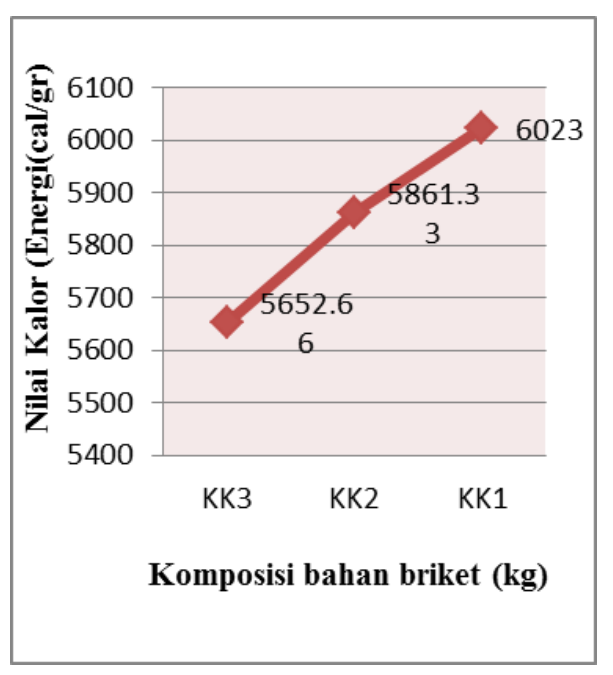

Gambar 4.1. Grafik komposisi bahan terhadap nilai kalor

Pada grafik diatas dapat dilihat bahwa pengujian nilai kalor terhadap ketiga jenis briket menghasilkan nilai kalor yang paling rendah pada briket KK3 sebesar 
$5652.66 \mathrm{cal} / \mathrm{gr}$, kemudian diikuti dengan briket KK2 sebesar $5861.33 \mathrm{cal} / \mathrm{gr}$, dan yang memghasilkan nilai kalor paling tinggi adalah briket KK1 sebesar 6023 cal/gr. Nilai kalor yang dihasilkan dari ketiga jenis briket berbeda - beda dikarenakan variasi komposisi campuran bahan baku.

\section{Hasil pengujian pembakaran briket dan pendidihan air pada kompor briket dan efisiensi thermal}

Metode pembakaran dengan mendidihkan air dalam panci sebanyak 800 gram dan mencatat temperatur api dan air setiap 5 menit sampai air dalam panci mendidih. Setelah mendidih (temperatur $100^{\circ} \mathrm{C}$ ), kemudian air panas dikeluarkan dari panci untuk ditimbang beratnya. Setelah itu panci kembali diisi dengan air yang baru, siap dididihkan ulang. Hal ini dilakukan secara berulang-ulang sampai briket tidak bisa lagi untuk mendidihkan air. Pengujian dilanjutkan dengan menimbang briket sisa pembakaran dan menimbang berat air yang telah mendidih. Berat briket yang digunakan pada pengujian adalah tetap yaitu sebesar 350 gram sedangkan berat panci aluminium yang digunakan 250 gram.

Berikut adalah hasil pembakaran briket dan pendidihan air pada 3 jenis briket limbah campuran buah pinus dan sekam padi berdasarkan komposisi campuran bahan :

Hasil pengujian pembakaran pada kompor dengan ketiga jenis briket.

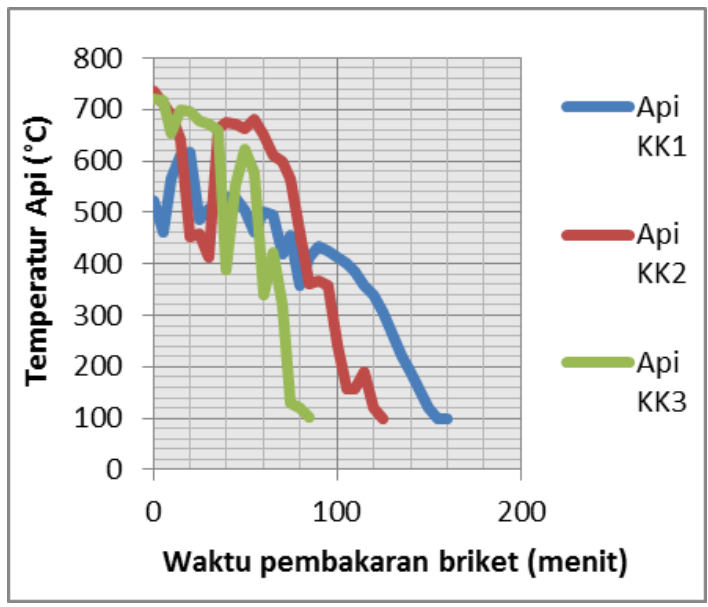

Gambar 4.2 Grafik waktu pembakaran briket terhadap temperature api pada ketiga jenis briket. 
Pengujian pembakaran dengan menggunakan briket campuran buah pinus dengan sekam padi dengan variasi komposisi bahan yaitu briket KK1 dengan campuran arang buah pinus 625 gr, arang sekam padi 225 gr, tanah liat 75 gr, tepung tapioca 75 gr, briket KK2 dengan campuran arang buah pinus 225 gr, arang sekam padi 625 gr, tanah liat 75 gr, tepung tapioca 75 gr, kemudian briket KK3 dengan campuran arang 425 gr, arang sekam padi 425 gr, tanah liat 75 gr, tepung tapioca 75 gr. Menghasilkan grafik waktu pembakaran briket terhadap temperature api pada kompor, diperlihatkan dalam Gambar di atas. Ketiga jenis briket campuran buah pinus dan sekam padi temperatur maksimal yang diberikan KK1 pada kompor yaitu $617{ }^{\circ} \mathrm{C}$ yang dicapai pada menit ke 20 dan temperature akhir yang diberikan briket pada kompor adalah $98{ }^{\circ} \mathrm{C}$ pada menit ke 160 , temperatur maksimal yang diberikan KK2 pada kompor yaitu $739{ }^{\circ} \mathrm{C}$ yang dicapai pada menit ke 1 dan temperature akhir yang diberikan briket pada kompor adalah $100{ }^{\circ} \mathrm{C}$ pada menit ke 125 , dan temperatur maksimal yang diberikan KK3 pada kompor yaitu $719^{\circ} \mathrm{C}$ yang dicapai pada menit ke 1 dan temperature akhir yang diberikan briket pada kompor adalah $101^{\circ} \mathrm{C}$ pada menit ke 85 .

Hasil pengujian pendidihan air pada kompor dengan ketiga jenis briket.

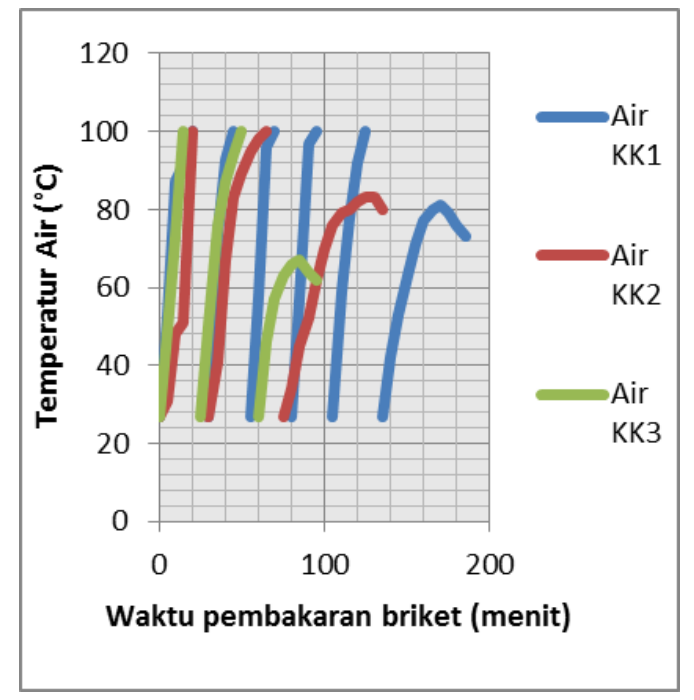

Gambar 4.3.Grafik waktu pembakaran briket terhadap temperature air peda ketiga jenis briket. 
Pengujian pemanasan air dengan menggunakan briket campuran buah pinus dan sekam padi dengan variasi campuran bahan yaitu briket KK1 dengan campuran arang buah pinus 625 gr, arang sekam padi 225 gr, tanah liat 75 gr, tepung tapioca 75 gr, briket KK2 dengan campuran arang buah pinus 225 gr, arang sekam padi 625 gr, tanah liat 75 gr, tepung tapioca 75 gr, kemudian briket KK3 dengan campuran arang 425 gr, arang sekam padi 425 gr, tanah liat 75 gr, tepung tapioca $75 \mathrm{gr}$.

Menghasilkan grafik waktu pembakaran briket terhadap temperatur air, diperlihatkan dalam Gambar di atas. Pemanasan air dengan menggunakan briket campuran buah pinus dengan sekam padi KK1 membutuhkan waktu 160 menit dan dapat mendidihkan air $0.8 \mathrm{~kg}$ sebanyak 5 kali yaitu masing-masing pada menit ke 19, 39, 59, 80, dan menit ke 104 .

Selanjutnya tidak dapat lagi mendidihkan air dan hanya mampu memanaskan air sampai temperatur $73{ }^{\circ} \mathrm{C}$, kemudian turun, untuk briket $\mathrm{KK} 2$ membutuhkan waktu 125 menit dan dapat mendidihkan air $0.8 \mathrm{~kg}$ sebanyak 2 kali yaitu masing-masing pada menit ke ke 17, dan menit ke 56. Selanjutnya tidak dapat lagi mendidihkan air dan hanya mampu memanaskan air sampai temperatur $80^{\circ} \mathrm{C}$, kemudian turun dan briket KK3 membutuhkan waktu 85 menit dan dapat mendidihkan air $0.8 \mathrm{~kg}$ sebanyak 2 kali yaitu masing-masing menit ke 14, dan menit ke 43. Selanjutnya tidak dapat lagi mendidihkan air dan hanya mampu memanaskan air sampai temperature $62^{\circ} \mathrm{C}$, kemudian turun.

\section{KESIMPULAN}

1. Berdasarkan hasil pengujian nilai kalor, briket yang memiliki nilai kalor tertinggi adalah KK1 yaitu sebesar $6023 \mathrm{cal} /$ gram, kemudian diikuti KK2 yaitu sebesar $5861.33 \mathrm{cal} /$ gram, dan yang paling rendah adalah KK3 yaitu sebesar $5652.66 \mathrm{cal} / \mathrm{gram}$.

2. Berdasarkan hasil perhitungan efisiensi pembakaran menunjukkan bahwa KK1 mempunyai efisiensi tertinggi yaitu $62.7 \%$, disusul KK2 sebesar $25 \%$ dan yang paling rendah KK3 sebesar $22 \%$. Jadi semakin tinggi nilai kalor maka semakin tinggi juga efisiensi thermalnya. 


\section{Saran}

Untuk mendapatkan briket arang campuran buah pinus dengan sekam padi dengan hasil terbaik maka diperlukan penelitian lanjutan dengan komposisi campuran dari bahan baku lain untuk meningkatkan efisiensi termal pada pembakaran briket.

\section{DAFTAR PUSTAKA}

I Wayan Nyoman., 2016. Variasi Waktu Pembakaran Pada Pirolisis Fluidasasi Briket Batok Kelapa Terhadap analisis proksimat. Jurnal Nasional Metlik Volume 2 No.1 April 2016.

Idzi Qistina, Dede Sukandar, Trilaksono., 2016. Kajian Kualitas Briket Biomassa dari sekam Padi dan Tempurung Kelapa. Jurnal Kimia Valensi : Jurnal Penelitian Dan Pengembangan Ilmu Kimia November 2016.

Mangkau A (2012). Karakteristik Pembakaran Briket limbah Tongkol Jagung dan Sekam Padi Dengan Berbagai Perbandingan Tongkol Jagung Dan Sekam Padi. Laporan Penelitian Fakultas Teknik Universitas Hasanuddin.

Mahadir Sirman., 2013. Peningkatan Kualitas Briket Campuran Limbah Ketam Kayu Merbabu, Sekam Padi dan Tongkol Jagung Pada Berbagai Komposisi. Laporan Penelitian Fakultas Teknik Universitas Hasanuddin.

Makayasa Erlangga., 2013. Pemanfaatan Limbah Sekam padi menjadi briket sebagai sumber energy alternative dengan proses karbonisasi dan Non Karbonisasi. Jurnal Kimia Promisi Vol. 2 No. 1Tahun 2013. ISSN 23373529

Naim Darum., 2015. Uji Karaktelistik briket arang dari limbah buah pinus dengan perekat tepung tapioca sebagai Bahan Bakar Alternatif. Seminar Nasional Teknik KimiaYogyakarta.

Qistina Idzi, Sukandar Dede, Trilaksono., 2016. Kajian Kualitas Briket Biomassa Dari Sekam Padi dan Tempurung kelapa. Jurnal Kimia Valensi : Jurnal Penelitian Dan Pengembangan Ilmu Kimia November 2016 halaman 236

Suluh Sallolo., 2014. Study of Performance Improvement Of Various Stoves With Waste Biomass Briquttes Fuel. Proceeding OF The International Symposium On Smart Material And Mechatronics Fakultas Teknik Universitas Hasanuddin Tahun 2014 pages 39-45. 
DYNAMIC SAINT

JDS, Jilid III no. 2, April 2018

Syahrir M., 2014. Limbah Batang Jagung Sebagai Sumber Energy Alternatif. Prosiding Seminar Nasional Rekayasa Material, Sistem Manufaktur dan Energi Hal III-155.

Siregar Rifai Ahmad., 2014. Pemanfaatan sekam padi dan limbah the sebagai briket dengan perekat tetes tebu. Jurnal Nasional Rekayasa Pertanian Vol 3 No. 3 Tahun 2014. 